\title{
Familial male-limited precocious puberty
}

INSERM

\section{Source}

INSERM. (1999). Orphanet: an online rare disease and orphan drug data base. Familial male-limited precocious puberty. ORPHA:3000

Familial male limited precocious puberty (FMPP) is a gonadotropin-independent familial form of male-limited precocious puberty, generally presenting between 2-5 years of age as accelerated growth, early development of secondary sexual characteristics and reduced adult height. 